\section{Retrospective study on the hygienic quality of fresh ricotta cheeses produced in Sicily, Italy}

\author{
Maria Luisa Scatassa, ${ }^{1}$ \\ Isabella Mancuso, ${ }^{1}$ Sonia Sciortino, ${ }^{1}$ \\ Giusi Macaluso, ${ }^{1}$ Marisa Palmeri, ${ }^{1}$ \\ Luigi Arcuri, ${ }^{2}$ Massimo Todaro, ${ }^{3}$ \\ Cinzia Cardamone ${ }^{1}$ \\ ${ }^{1}$ Institute for Experimental Veterinary \\ Medicine of Sicily “A. Mirri”, Palermo; \\ ${ }^{2}$ Local Health Unit, Palermo; \\ ${ }^{3}$ Department of Agricultural, Food and \\ Forest Sciences, University of Palermo, \\ Italy
}

\section{Abstract \\ The present work was carried out to} investigate the microbiological profile of Sicilian ewes' ricotta cheeses during fifteen years of investigations (2002-2016). The samples were collected between those conferred to the Istituto Zooprofilattico Sperimentale della Sicilia (IZSSi) Adelmo Mirri, Palermo (Italy), by the competent authority during official control, by food business operator in HACCP systems and in research projects. Enterobacteriaceae, Escherichia coli and coagulase-positive staphylococci (CPS) were found only in some samples. Bacillus cereus was detected in c.a. $16 \%$ of samples but the level of contaminations did not reach the threshold that leads to significant toxin production. Pathogenic bacteria such as Listeria monocytogenes, Salmonella spp. and Brucella spp. were never detected. Furthermore, a total of 47 of lactic acid bacteria (LAB) strains were identified at species level by sequencing the $16 \mathrm{~S}$ rRNA gene, resulting in the identification of 10 species belonging to four genera Enterococcus, Lactobacillus, Lactococcus and Leuconostoc, commonly employed as starter and non starter cultures in different traditional cheese. Results of this study highlighted an improvement of the hygienic conditions of the Sicilian ewes' ricotta cheeses during the last ten years of investigation. This observation was confirmed from reduction of undesired microorganisms such as Enterobacteriaceae, E.coli and CPS, used to define the process hygiene criteria. However, in order to improve the final quality of this product are needed further strategy such as the dairy makers training, with the aim to apply a good hygienic practices during the production.

\section{Introduction}

Recently, the new trends of life style of the consumer showed an increasing demand of traditional dairy products manufactured at the small dairy level (Gaglio et al., $2014 b$ ). Furthermore, the consumers require foods processed without chemical preservatives and characterized by low-fat and highnutritional values. Ricotta could respond to the demands of consumers because it is characterized by high quantity of proteins, low fat and salt content and other important components, which give this product a high nutritional value (Guatemim et al., 2016).

Ricotta is a fresh dairy product that has soft, grainy, thick, lightly sour taste and presents a white colour. Usually, it can be eaten as a soft cheese but in Sicily is more frequently used as an ingredient in dishes and desserts. The name derived from the Latin word re-cocta, literally recooked or cooked twice. In Sicily it is generally manufactured from the ewes' whey remaining after the production of hard semi-cooked cheese (Pecorino Siciliano PDO) and fresh cheese (Vastedda della valle del Belìce PDO) but can be produced also with goat, cow and buffalo whey milk. Ricotta production technology uses the principle of coagulation and precipitation of the whey proteins such as globulin and albumin favoured by whey acidification at $\mathrm{pH}<5.6$ and by heating at $80-90^{\circ} \mathrm{C}$. During the production of Sicilian ewes' ricotta cheese, the whey is enriched with whole raw ewes' milk (5-15\%) and salt $(0.5-1.5 \%)$ to increase the yield and improve the organoleptic characteristics. Fresh ricotta is characterized by a short shelflife because of its high moisture level, high concentration of residual sugars and an initial $\mathrm{pH}$ above 6.0 which make this product an excellent growth medium for a wide range of microorganisms (Mancuso et al., 2014). The attributed shelflife of ricotta cheese is generally comprised between 7-11 days under refrigerated storage $\left(4^{\circ} \mathrm{C}\right)$.

Some of the microorganisms that grow in dairy products are able to produce undesirable reactions that deteriorate the organoleptic characteristics of cheese, while other can potentially cause food-borne diseases (Lu et al., 2013).

The presence of these microorganisms in dairy productions depends in some factors such as the quality of raw material, the respect of good practices of production and storage conditions (Ledenbach and Marshall, 2009).

In this context the present work was aimed to evaluate the microbiological quality of several samples of Sicilian ewes' ricotta cheese collected from dairy factories and small and large distribution.
Correspondence: Maria Luisa Scatassa, Istituto Zooprofilattico Sperimentale della Sicilia “A. Mirri", Via Gino Marinuzzi 3, 90129 Palermo, Italy

Tel. + +39.091.6565300 - Fax +39.091.6565332. E-mail: luisa.scatassa@izssicilia.it

Key words: Ricotta cheese; Microbial community; Lactic acid bacteria; hygienic quality; food safety

Acknowledgments: The Authors thanks V. Alio, A. Carrozzo, B. Ducato and G. Oliveri for their precious collaboration.

Contributions: the authors contributed equally.

Conflict of interests: the authors declare no potential conflict of interests

Received for publication: 19 July 2017. Revision received: 12 October 2017. Accepted for publication: 14 October 2017.

This work is licensed under a Creative Commons Attribution-NonCommercial 4.0 International License (CC BY-NC 4.0).

CC Copyright M.L. Scatassa et al., 2018

Licensee PAGEPress, Italy

Italian Journal of Food Safety 2018; 7:6911

doi:10.4081/ijfs.2018.6911

\section{Materials and Methods}

\section{Sample collections}

A total of 1295 samples of ewes' ricotta cheeses were collected between those conferred to the Istituto Zooprofilattico Sperimentale della Sicilia (IZSSi) Adelmo Mirri, Palermo (Italy), by the competent authority during official control, by food business operator in HACCP systems and in research projects. The samples were collected from 36 bakeries and pastry shops; from 233 markets and large-scale retail trade and from 365 dairy factories. The samples were collected during fifteen years of investigation (2002-2016). All samples to be microbiologically investigated were transported under refrigeration at the laboratories of the above-mentioned institute.

\section{Microbiological analysis and $\mathrm{pH}$ measurement}

All samples were analyzed in accordance with international standard or validated method: Total mesophilic count (ISO 4833), sulphite reducing anaerobes (ISO 15213), Enterobacteriaceace (ISO 4832), Escherichia coli (ISO 16649-2); coagulasepositive staphylococci (CPS, ISO 6888-2); Bacillus cereus (ISO 7932); yeasts and 
moulds (ISO 21527-1), Pseudomonas (ISO 11059), enterococci on Kanamycin Aesculin Azide aerobically incubated at $37^{\circ} \mathrm{C}$ for $24-48 \mathrm{~h}$, rod-shaped lactic acid bacteria (LAB) on de Man-Rogosa-Sharpe (MRS) agar, acidified to $\mathrm{pH} 5.4$ with lactic acid $\left(5\right.$ mol. $\left.\mathrm{L}^{-1}\right)$ and incubated anaerobically for $48 \mathrm{~h}$ at $37^{\circ} \mathrm{C}$; and mesophilic and thermophilic coccus-shaped LAB on M17 agar and incubated aerobically for $48 \mathrm{~h}$ at 30 and $44^{\circ} \mathrm{C}$, respectively. Salmonella spp. was detected using ISO 6579 or AFNOR BIO 12/23-05/07 and Listeria monocytogenes using ISO $11290-1$ or AFNOR BIO 12/11-03/04. Brucella spp. using Manual of Diagnostic Tests and Vaccines for Terrestrial Animals, cap. 2.4.3.:2009.

The $\mathrm{pH}$ value of ricotta samples was monitored electrometrically using a portable food and dairy $\mathrm{pH}$ meter HI322002 (Hanna Instruments, Woonsocket, Rhode Island, USA).

\section{Isolation, phenotypic characteriza- tion and identification of $\mathrm{LAB}$}

Some colonies of various shapes were picked up from count plates used for LAB (MRS and M17) enumeration. The isolates from MRS and M17 were transferred to the corresponding broth media. The isolates were purified by successive sub-culturing and the purity of the isolates, as well as the cell morphology were checked microscopically. Gram-positive and catalase-negative were stored in glycerol at $-80^{\circ} \mathrm{C}$ until further experimentations.

Lactic acid bacteria isolates were genetically identified by $16 \mathrm{~S}$ rRNA gene sequencing. The DNA from ricotta $\mathrm{LAB}$ isolates was extracted using the InstaGene Matrix kit (Bio-Rad laboratories, Hercules, CA) according to the manufacturer's instructions. Crude cell extracts were used as templates for the polymerase chain reactions (PCRs). PCRs were performed as described by Weisburg et al. (1991) using the primers rD1 (5'-AAGGAGGTGATCCAGCC-3') and fD1 (5'AGAGTTTGATCCTGGCTCAG-3'). DNA sequences were determined by using an ABI PRISM 3130 Genetic Analyzer (Applied Biosystems, Carlsbad, CA, USA) and compared using a BLAST search in the GenBank/ EMBL/DDBJ database (http://www.ncbi.nlm. nih.gov).

\section{Statistical analysis}

Microbiological data of ricotta cheeses divided in three 5-year periods of investigation (2002-2006; 2007-2011; 2012-2016) were subjected to statistical analysis. The logarithm values of microbiological parameters were performed using 1-factor ANOVA model with a 5-year periods as fixed factor (SAS, 2010). Least square means were compared using the $t$ Student test.

\section{Results and Discussion}

\section{Microbiological counts and $\mathrm{pH}$ val- ues of Ricotta samples}

The microbial loads of the ricotta samples collected during fifteen years of inves- tigation are reported in Table 1 . The results reported in this table are referred only to the microbial group that showed a microbiological grow (positive samples).

The total microbial count (TMC) and LAB concentrations detected in this study were, on average, 1 Log cycle higher than those reported in our previous work (Mancuso et al., 2014), who studied the sensory and microbiological evaluation of traditional ovine ricotta cheese in modified atmosphere packaging (MAP). Furthermore, Spanu and coworkers (2017) always in a study conducted in MAP packed ricotta cheese previously inoculated with commercial biopreservatives and analyzed at different time of refrigerated storage found at $\mathrm{t}_{0}$ (after $5 \mathrm{~h}$ from the production) a lower concentration of TMC and LAB. This may be due to different conditions of packaging and refrigerated storage used in the studies. Enterobacteriaceae and E. coli were found in c.a. $21 \%$ and $13 \%$ of samples, respectively as reported by Fadda et al. (2012) with an average values of the Enterobacteriaceae between 3 and $4 \log$ CFU/g (Pala et al., 2016). Thirty four samples $(43.6 \%$ on the total positive samples) showed a concentration of $E$. coli higher of $1000 \mathrm{UFC} / \mathrm{g}$ that represents the maximum enumeration limit for cheeses made from milk or whey that has undergone heat treatment according to Reg. (EC) 2073/2005. The highest level of $E$. coli detected in ricotta cheese samples was equal to $6.89 \mathrm{log}$ $\mathrm{CFU} / \mathrm{g}$.

Enterobacteriaceae and E. coli are not able to survive at the thermal treatment of the whey, to this purpose their presence in

Table 1. Microbial loads of ricotta samples.

\begin{tabular}{|c|c|c|c|c|c|c|c|}
\hline Microorganisms* & Number of samples & Positive samples & $\%$ positive samples & Mean & Min. & Max. & SD \\
\hline TMC & 371 & 350 & 94.34 & 5.11 & 2 & 8.26 & 1.63 \\
\hline Rod LAB $\left(37^{\circ} \mathrm{C}\right)$ & 98 & 74 & 75.51 & 3.6 & 1.85 & 5.58 & 1.16 \\
\hline Coccus $\mathrm{LAB}\left(30^{\circ} \mathrm{C}\right)$ & 98 & 82 & 83.67 & 3.73 & 2.00 & 6.83 & 1.38 \\
\hline Coccus LAB $\left(44^{\circ} \mathrm{C}\right)$ & 98 & 69 & 70.41 & 3.09 & 1.78 & 4.85 & 0.92 \\
\hline Enterococci & 106 & 40 & 37.74 & 3.67 & 1.77 & 6.20 & 1.18 \\
\hline Enterobacteriaceae & 371 & 78 & 21.02 & 3.68 & 1.43 & 7.00 & 1.26 \\
\hline E. coli & 598 & 78 & 13.04 & 3.26 & 1.3 & 6.89 & 1.29 \\
\hline CPS & 639 & 14 & 2.19 & 3.11 & 1.56 & 5.38 & 1.27 \\
\hline Yeasts and moulds & 88 & 12 & 13.64 & 2.68 & 1.00 & 4.00 & 0.97 \\
\hline B. cereus & 157 & 25 & 15.92 & 3.79 & 1.70 & 6.00 & 0.95 \\
\hline Pseudomonas & 91 & 2 & 2.20 & 1.98 & 1.96 & 2 & 0.03 \\
\hline SRA & 194 & 1 & 0.52 & & & & \\
\hline L. monocytogenes & 1156 & n.d. & n.d. & & & & \\
\hline Salmonella spp. & 998 & n.d. & n.d. & & & & \\
\hline Brucella spp. & 721 & n.d. & n.d. & & & & \\
\hline
\end{tabular}


ricotta cheese is usually attributed to secondary contamination that depend exclusively to the low hygienic conditions during production. The level of enterococci ranged between 1.78 and $6.20 \mathrm{Log} \mathrm{CFU} / \mathrm{g}$ with an overage value of $3.67 \mathrm{Log} \mathrm{CFU} / \mathrm{g}$ as reported by Pala et al. (2016). The presence of these bacteria in dairy products is usually associated with inadequate hygiene practices as a consequence of fecal contamination. However, several authors (Foulquié Moreno et al., 2006; Gaglio et al., 2016b) suggest that Enterococcus strains are involved in the development of the organoleptic characteristics especially in long ripened traditional cheeses and contribute to extend their shelf life. On the other hand, enterococci have assumed a major importance in clinical microbiology and their presence needs to be validated by the absence of risks for consumer in term of antibiotic resistance and virulence as well as cellular toxicity.

Yeasts and moulds between 1 and 4 Log CFU/g as reported by Pintado and Malcata (2000). Bacillus cereus was found in ca. $16 \%$ of the samples analysed with a viable count of $3.79 \pm 0.95 \mathrm{Log} C \mathrm{FU} / \mathrm{g}$. This results was similar to previously reported by Cosentino et al. (1997) who studied the incidence and biochemical characteristics of Bacillus flora in Sardinian dairy products, but lower than those reported by Spanu et al. (2016) in ricotta salata cheese analyzed after $24 \mathrm{~h}$ from production $\left(\mathrm{t}_{0}\right)$. However, the level of contaminations did not reach the threshold that leads to significant toxin production (EFSA 2016). Sulphite reducing anaerobe was found just in a one sample of 194 analyzed. The presence of $B$. cereus and SRA in ricotta samples depend from contamination of milk during transformation and to the ability of the spores to survive at the thermal treatment of the whey.

CPS were detected in a very low percentage of samples $(2.19 \%)$ and their level ranged between 1.56 and $5.38 \mathrm{Log} \mathrm{CFU} / \mathrm{g}$. Only two samples showed a final concentration above $5.00 \mathrm{Log} \mathrm{CFU} / \mathrm{g}$ that represents the threshold that leads to staphylococcal enterotoxins production (European Commission, 2005). Furthermore, the production of enterotoxins were never detected in both samples.

Spoilage psychotrophic bacteria such as Pseudomonas spp. were detected just in two samples with showed an mean values of $1.98 \pm 0.03 \mathrm{Log} \mathrm{CFU} / \mathrm{g}$ lower than those reported by Spanu et al. (2017). This may be due to that the 91 samples tested for the presence of this microbial group were conferred to the IZSSi in a higher percentage from large-scale retail trade and in some cases from dairy factories characterized by high hygienic standards. Indeed, usually the presence of this microbial group is a result of a secondary contaminations and their level increase during refrigeration storage. Their presence in ricotta cheeses can overgrow the other microflora and cause an spoilage of the final quality and the sensory profile of the products (Carrascosa et al., 2015; Pala et al., 2016).

Listeria monocytogenes, Salmonella spp. and Brucella spp. were never detected; this may be due to heat treatment of the whey used for the ricotta production that represent a killing step of these microorganisms and to the absence of secondary contamination from the processing environment. These results confirmed previous investigations performed in other Sicilian dairy environment and products where this pathogenic microorganisms were never detected (Cruciata et al., 2018; Gaglio et al., 2016a; Scatassa et al., 2015). Regarding the $\mathrm{pH}$, the ricotta samples showed a mean values of $6.37 \pm 0.33$ as reported by (Mucchetti and Neviani, 2006) but during the study were registered values ranged between 6.04 and 6.74

\section{Isolation, phenotypic characteriza- tion and identification of LAB}

A total of 98 cultures were collected from 30 ricotta cheese representative of the three level of sampling. All of the cultures were inspected microscopically and classified as cocci (69) or rods (29). Gram determination and the catalase test indicated that 64 cocci and 27 rods could be considered putative LAB cultures.

The 91 strains were identified by sequencing of the 16S rRNA gene. The strains were allotted into 10 species within the genera Enterococcus, Lactobacillus, Lactococcus and Leuconostoc. The species with the highest number of strains were Lactococcus lactis $(\mathrm{n}=23)$ e Lactobacillus casei $(\mathrm{n}=22)$. Other strains were identified as Enterococcus faecium $(\mathrm{n}=19)$, Leuconostoc lactis $(\mathrm{n}=7)$, Lactococcus lactis sub. lactis $(\mathrm{n}=6)$, Leuconostoc mesenteroides $(\mathrm{n}=6)$, Lactobacillus sakei $(\mathrm{n}=5)$. Enterococcus durans $(\mathrm{n}=1)$, Enterococcus faecalis $(\mathrm{n}=1)$ and Enterococcus gallinarum $(\mathrm{n}=1)$. Except $L$. lactis, all species identified are commonly reported to be part of the non starter LAB (NSLAB) population in several cheeses (Gatti et al., 2014). Furthermore, all these species were found in other traditional ewes' Sicilian cheeses (Gaglio et al., 2014a; Guarcello et al., 2016) and wooden equipment employed for cheese manufacture (Scatassa et al., 2015). Some works showed the ability of these LAB species to produce bacteriocin-like inhibitory substances (BLIS) active against Listeria and other pathogenic bacteria and this allows to improve the safety, control the fermentation microbiota, speed maturation and increase the shelf life of the final cheeses (Macaluso et al., 2016; Scatassa et al., 2017).

\section{Statistical analysis}

The statistical analysis of the microbiological counts conducted on the ricotta samples during three 5-year periods of investigation (2002-2006; 2007-2011 and 20122016) are reported in Table 2.

According to $t$ Student test, significant statistical differences were found for the levels of Enterococci, Enterobacteriaceae, yeasts and moulds, E. coli and CPS between the ricotta samples collected during the first 5 -years periods of investigation in comparison with the last two periods. A possible explanation to these observations is that in the last decade food business operators adopted the good hygiene and manufacturing practices, in compliance with the Commission Regulation (EC) No $2073 / 2005$ on microbiological criteria for foodstuffs (European Commission, 2005).

Table 2. Statistical analysis of microbial loads.

\begin{tabular}{lccc}
\hline Microorganisms* & $2002-2006$ & $2007-2011$ & $2012-2016$ \\
TMC & $5.33 \pm 1.13$ & $6.45 \pm 1.12$ & $4.78 \pm 0.75$ \\
Enterococci & $2.60 \pm 0.28^{\mathrm{a}}$ & $0.01 \pm 0.70^{\mathrm{b}}$ & $0.81 \pm 0.22^{\mathrm{b}}$ \\
\hline Enterobacteriaceae & $1.79 \pm 0.24^{\mathrm{a}}$ & $0.50 \pm 0.17^{\mathrm{b}}$ & $0.68 \pm 0.10^{\mathrm{b}}$ \\
E. coli & $1.33 \pm 0.09^{\mathrm{a}}$ & $0.24 \pm 0.08^{\mathrm{b}}$ & $0.19 \pm 0.07^{\mathrm{b}}$ \\
\hline CPS & $0.35 \pm 0.05^{\mathrm{a}}$ & $0.01 \pm 0.05^{\mathrm{b}}$ & $0.01 \pm 0.06^{\mathrm{b}}$ \\
Yeasts and moulds & $1.94 \pm 0.40^{\mathrm{a}}$ & $0.15 \pm 0.12^{\mathrm{b}}$ & $0.49 \pm 0.17^{\mathrm{b}}$ \\
\hline B. cereus & - & $0.67 \pm 0.11$ & $0.97 \pm 0.17$ \\
\hline
\end{tabular}

*Units are Log CFU/g. TMC, total mesophilic microorganisms; CPS, coagulase-positive staphylococci. On the row different letters are significant at $\mathrm{P} \leq 0.01$ 


\section{Conclusions}

The results reported in this study showed that from a hygienic point of view, the Sicilian ewes' ricotta represents a safe cheese production. In particular, during the entire periods of investigation the pathogenic bacteria (L. monocytogenes, Salmonella spp. and Brucella spp.) were never detected while the levels of undesired microorganisms such as Enterobacteriaceae, E.coli and CPS, during the last two 5-year periods of investigation were reduced in number in comparison with the first 5-year period of investigation. The last findings are not satisfactory since in that period the structural and hygienic conditions of dairies improved consistently. However, in order to improve the final quality of this product are needed further strategy such as the dairy makers training, with the aim to apply a good hygienic practices during the production.

\section{References}

Carrascosa C, Millán R, Jaber JR, Lupiola P, del Rosario-Quintana C, Mauricio C, Sanjuán E, 2015. Blue pigment in fresh cheese produced by Pseudomonas fluorescens. Food Control 54:95-102.

Cosentino S, Mulargia AF, Pisano B, Tuveri P, Palmas F, 1997. Incidence and biochemical characteristics of Bacillus flora in Sardinian dairy products. Int J Food Microbiol 38:235-8.

Cruciata M, Gaglio R, Scatassa ML, Sala G, Cardamone C, Palmeri M, Moschetti G, La Mantia T, Settanni L, 2018. Formation and characterization of early bacterial biofilms on different wood typologies applied in dairy production. Appl Environ Microbiol 84:e02107-17.

EFSA, 2016. Risks for public health related to the presence of Bacillus cereus and other Bacillus spp. including Bacillus thuringiensis in foodstuffs. EFSA $\mathrm{J}$ 14:4524.

European Commission, 2005. Commission Regulation No 2073/2005 of 15 November 2005 on microbiological criteria for foodstuffs. In: Off J Eur Union, L 338/1, 22/12/2005.

Fadda A, Delogu A, Mura E, Noli AC, Porqueddu G, Rossi ML, Terrosu G, 2012. Presence of Bacillus cereus, Escherichia coli and Enterobacteriaceae in fresh and salted ricotta cheese: official controls in Sardinia during the period 2009-2012. Ital J Food Safety 1:43-5.

Foulquié Moreno MR, Sarantinopoulos P, Tsakalidou E, De Vuyst L, 2006. The role and application of enterococci in food and health. Int J Food Microbiol
106:1-24

Gaglio R, Francesca N, Di Gerlando R, Cruciata M, Guarcello R, Portolano B, Moschetti G, Settanni L. 2014a. Identification, typing, and investigation of the dairy characteristics of lactic acid bacteria isolated from "Vastedda della valle del Belìce" cheese. Dairy Sci Technol 94:157-80.

Gaglio R, Scatassa ML, Cruciata M, Miraglia V, Corona O, Di Gerlando R, Portolano B, Moschetti G, Settanni L. $2014 b$. In vivo application and dynamics of lactic acid bacteria for the four-season production of Vastedda-like cheese. Int J Food Microbiol 177:37-48.

Gaglio R, Cruciata M, Di Gerlando R, Scatassa ML, Mancuso I, Sardina MT, Moschetti G, Portolano B, Settanni L, 2016a. Microbial activation of wooden vats used for traditional cheese production and evolution of the neo-formed biofilms. Appl Environ Microbiol 82:585-95.

Gaglio R, Couto N, Marques C, Lopes MDFS, Moschetti G, Pomba C, Settanni L, 2016b. Evaluation of antimicrobial resistance and virulence of enterococci from equipment surfaces, raw materials, and traditional cheeses. Int $\mathrm{J}$ Food Microbiol 236,107-14.

Gatti M, Bottari B, Lazzi C, Neviani E, Mucchetti G, 2014. Invited review: microbial evolution in raw-milk, longripened cheeses produced using undefined natural whey starters. J Dairy Sci 97:573-91.

Guarcello R, Carpino S, Gaglio R., Pino A, Rapisarda T, Caggia C, Marino G, Randazzo CL, Settanni L, Todaro M, 2016. A large factory-scale application of selected autochthonous lactic acid bacteria for PDO Pecorino Siciliano cheese production. Food Microbiol 59:66-75.

Guatemim ELX, Silveira SMD, Millezi AF, Ferenz M, Costa KD, Rossi P, Bampi GB, 2016. Evaluation of the microbiological quality of ricotta cheese commercialized in Santa Catarina, Brazil. Food Sci Technol 36:612-5.

Ledenbach LH, Marshall RT, 2009. Microbiological spoilage of dairy products. In: Sperber WH, Doyle MP, eds. Compendium of the Microbiological Spoilage of Foods and Beverages, Food Microbiology and Food Safety. Springer Science Business Media B.V. Dordrecht, Netherlands.

Lu M, Shiau Y, Wong J, Lin R, Kravis H, Blackmon T, Pakzad T, Jen T, Cheng A, Chang J, Ong E, Sarfaraz N, Wang NS, 2013. Milk spoilage: methods and practices of detecting milk quality. Food Nutr Sci 4:113-23.
Macaluso, G., Fiorenza, G., Gaglio, R., Mancuso, I., Scatassa, M.L. 2016. In vitro evaluation of bacteriocin-like inhibitory substances (BLIS) produced by lactic acid bacteria isolated during traditional Sicilian cheese making. Ital J Food Safety 5:20-2.

Mancuso I, Cardamone C, Fiorenza G, Macaluso G, Arcuri L, Miraglia V, Scatassa ML 2014. Sensory and microbiological evaluation of traditional ovine ricotta cheese in modified atmosphere packaging. Ital J Food Safety 3:22-4.

Mucchetti G, Neviani E, 2006. Microbiologia e tecnologia lattierocasearia. In: Qualità e sicurezza. Tecniche Nuove, Milano.

Pala C, Scarano C, Venusti M, Sardo D, Casti D, Cossu F, Lamon S, Spanu V, Ibba M, Marras M, Paba A, Spanu C, De Santis EPL, 2016. Shelf life evaluation of ricotta fresca sheep cheese in modified atmosphere packaging. Ital J Food Safety 5:134-9.

Pintado ME, Malcata FX, 2000 Characterization of whey cheese packaged under vacuum. J Food Prot 63: 21621.

Spanu C, Scarano C, Spanu V, Pala C, Casti D, Lamon S, Cossu F, Ibba M, Nieddu G, De Santis EPL, 2016. Occurrence and behavior of Bacillus cereus in naturally contaminated ricotta salata cheese during refrigerated storage. Food Microbiol, 58:135-8.

Spanu C, Scarano C, Piras F, Spanu V, Pala C, Casti D, Lamon S, Cossu F, Ibba M, Nieddu G, De Santis EPL, 2017. Testing commercial biopreservative against spoilage microrganisms in MAP packed Ricotta fresca cheese. Food Microbiol, 66:72-6.

Scatassa ML, Gaglio R, Macaluso G, Francesca N, Randazzo W, Cardamone C, Di Grigoli A, Moschetti G, Settanni L, 2015. Transfer, composition and technological characterization of the lactic acid bacterial populations of the wooden vats used to produce traditional stretched cheeses. Food Microbiol, 52:31-41.

Scatassa ML, Gaglio R, Cardamone C, Macaluso G, Arcuri L, Todaro M, Mancuso I, 2017. Anti-Listeria activity of lactic acid bacteria in two traditional Sicilian cheeses. Ital J Food Safety 5:137.

Weisburg WG, Barns SM, Pelletier DA, Lane DJ, 1991. 16S ribosomal DNA amplification for phylogenetic study. J Bacteriol 173:697-703. 